\title{
CHILD'S GENDER AND BASELINE BMI Z-SCORE - THE MAIN PREDICTORS OF SUCCESS IN THE FIRST PAEDIATRIC WEIGHT CORRECTION PROGRAMME IN LATVIA
}

\section{Presenting author: Dana Apela}

Graduate medical training (Residency in Medicine), Faculty of Continuing Education, Riga Stradins University, Latvia Children's Clinical University Hospital, Riga, Latvia

\section{Co-author: Jurgita Gailite}

Endocrinology Department, Children's Clinical University Hospital, Riga, Latvia

Faculty of Medicine, Riga Stradins University, Riga, Latvia

\section{BACKGROUND AND AIMS}

According to WHO, $21.5 \%$ of at least five years old children were overweight in Latvia in 2016 (1). Most of children retain their excess weight into the adulthood if no intervention is done (2). The main and often the only available kind of intervention is a nonsurgical, nonpharmacological therapy in a multidisciplinary weight correction programme (3). There are lots of different possible predictors studied around the world that may affect the success of paediatric weight correction programmes. The aim of this study was to find the best available predictors of success in the first paediatric weight correction programme in Latvia.

\section{METHODS}

The respondents of this study were patients of Weight Correction Programme at Children's Clinical University Hospital in Riga. The inclusion criteria: first day in programme from August 2014 until June 2017; at least 5 years old; at least one follow-up visit data available. Further on random sample was obtained from all patients that met inclusion criteria. The main outcome was the number of good responders - those that reduced BMI Z-score by at least .20 units. The predictors were evaluated by using binary logistic regression. The probability value $p<.05$ was considered significant.

\section{RESULTS}

There were 135 (75\%) respondents randomly included from all 181 that met the inclusion criteria. The mean age was 12.0 (SD 2.7) years. There were 61 (45\%) boys. 46 (34\%) patients managed to reduce their BMI z-score by at least 0.20 units. The regression results are shown in table 1.

\section{CONCLUSIONS}

Boys have higher odds to reduce their BMI z-score by at least 0.20 units than girls. Baseline BMI z-score is a positive predictor - the more excess weight in the first place, the biggest chance of clinically significant BMI z-score reduction afterwards.

Table 1. Odds Ratios for losing at least .20 units of BMI z-score $(\mathbf{N}=135)$

OR - Odds Ratios; $\mathrm{Cl}$ - Confidence interval; Sig. - Significance; z-BMI - body mass index z-score.

\begin{tabular}{|c|c|c|c|c|c|c|}
\hline & OR & $95 \% \mathrm{Cl}$ & Sig. & Adjusted OR & $95 \% \mathrm{Cl}$ & Sig. \\
\hline $\begin{array}{r}\text { Gender } \\
\text { (Reference: girls) }\end{array}$ & 2.64 & $1.27-5.49$ & 0.009 & 2.40 & $1.07-5.38$ & 0.034 \\
\hline $\begin{array}{r}\text { Birth Weight } \\
\text { (per } 100 \text { grams increase) }\end{array}$ & 1.00 & 0.94-1.07 & 0.902 & 0.98 & $0.92-1.05$ & 0.524 \\
\hline $\begin{array}{r}\text { Age } \\
\text { (per year increase) }\end{array}$ & 0.93 & $0.81-1.06$ & 0.276 & 1.03 & $0.89-1.20$ & 0.702 \\
\hline $\begin{array}{l}\text { Baseline z-BMI } \\
\text { (per unit increase) }\end{array}$ & 2.11 & $1.27-3.49$ & 0.004 & 1.84 & $1.05-3.21$ & 0.032 \\
\hline $\begin{array}{r}\text { Follow-up time } \\
\text { (per month increase) }\end{array}$ & 1.03 & $0.98-1.08$ & 0.253 & 1.00 & $1.00-1.00$ & 0.236 \\
\hline
\end{tabular}

\section{SOURCES}

1. WHO | Overweight and obesity. World Health Organization; 2017. [Cited: 2018 Jun 12] Available from: URL: http://www.who.int/gho/ncd/risk_factors/overweight_obesity/overweight_adolescents/en/

2. WHO. Report of the Commission on Ending Childhood Obesity: implementation plan: executive summary. World Health Organization; 2017.

3. American Academy of Pediatrics Institute for Healthy Childhood Weight. Algorithm for the assessment and management of childhood obesity in patients 2 years and older. August 2016. 